\title{
Adolescent THC exposure does not sensitize conditioned place preferences to subthreshold d-amphetamine in male and
} female rats [version 1; peer review: 2 approved]

\author{
Robin J Keeley (D1,2, Cameron Bye ${ }^{1}$, Jan Trow¹, Robert J McDonald (iD1 \\ ${ }^{1}$ University of Lethbridge, 4401 University Drive, Lethbridge, AB, T1K 3M4, Canada \\ ${ }^{2}$ National Institute on Drug Abuse, 251 Bayview blvd, Suite 200, Baltimore, MD, 21224, USA
}

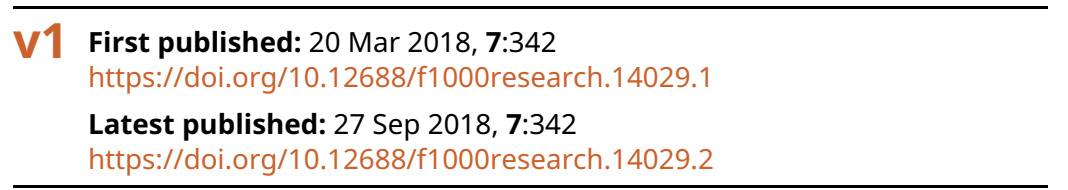

\section{Abstract}

The acute effects of marijuana consumption on brain physiology and behaviour are well documented, but the long-term effects of its chronic use are less well known. Chronic marijuana use during adolescence is of increased interest, given that the majority of individuals first use marijuana during this developmental stage, and adolescent marijuana use is thought to increase the susceptibility to abusing other drugs when exposed later in life. It is possible that marijuana use during critical periods in adolescence could lead to increased sensitivity to other drugs of abuse later on. To test this, we chronically administered $\Delta^{9}$-tetrahydrocannabinol (THC) to male and female Long-Evans (LER) and Wistar (WR) rats directly after puberty onset. Rats matured to postnatal day 90 before being exposed to a conditioned place preference task (CPP). A subthreshold dose of damphetamine, found not to induce place preference in drug naïve rats, was used as the unconditioned stimulus. The effect of $d$ amphetamine on neural activity was inferred by quantifying cfos expression in the nucleus accumbens and dorsal hippocampus following CPP training. Chronic exposure to THC post-puberty had no potentiating effect on a subthreshold dose of d-amphetamine to induce CPP. No differences in cfos expression were observed. These results show that chronic exposure to THC during puberty did not increase sensitivity to d-amphetamine in adult LER and WR rats. This supports the concept that THC may not sensitize the response to all drugs of abuse.

Keywords

THC, adolescence, d-amphetamine, strain, sex, conditioned place preference

\author{
Open Peer Review \\ Approval Status \\ 1 \\ 2 \\ version 2 \\ (revision) \\ 27 Sep 2018 \\ version 1 \\ 20 Mar 2018

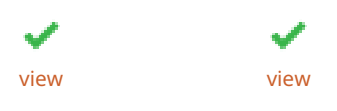 \\ 1. Ryan J. McLaughlin (D), Washington State \\ University, Pullman, USA \\ Timothy G. Freels , University of \\ Memphis, Memphis, USA \\ 2. Jibran Y. Khokhar, University of Guelph, \\ Guelph, Canada
}

Any reports and responses or comments on the article can be found at the end of the article. 
Corresponding author: Robin J Keeley (robin.keeley@nih.gov)

Author roles: Keeley RJ: Conceptualization, Data Curation, Formal Analysis, Investigation, Methodology, Project Administration, Validation, Visualization, Writing - Original Draft Preparation, Writing - Review \& Editing; Bye C: Investigation, Writing - Review \& Editing; Trow J: Methodology; McDonald RJ: Conceptualization, Funding Acquisition, Methodology, Project Administration, Resources, Supervision, Validation, Writing - Review \& Editing

Competing interests: No competing interests were disclosed.

Grant information: NSERC Discovery Grant

The funders had no role in study design, data collection and analysis, decision to publish, or preparation of the manuscript.

Copyright: ๑ 2018 Keeley RJ et al. This is an open access article distributed under the terms of the Creative Commons Attribution License , which permits unrestricted use, distribution, and reproduction in any medium, provided the original work is properly cited. Data associated with the article are available under the terms of the Creative Commons Zero "No rights reserved" data waiver (CC0 1.0 Public domain dedication).

How to cite this article: Keeley RJ, Bye C, Trow J and McDonald RJ. Adolescent THC exposure does not sensitize conditioned place preferences to subthreshold d-amphetamine in male and female rats [version 1; peer review: 2 approved] F1000Research 2018, 7 :342 https://doi.org/10.12688/f1000research.14029.1

First published: 20 Mar 2018, 7:342 https://doi.org/10.12688/f1000research.14029.1 


\section{Introduction}

Marijuana is one of the most commonly used drugs of abuse worldwide $^{1}$, and the psychoactive properties of marijuana are a result of the actions of $\Delta^{9}$-tetrahydrocannabinol (THC) $)^{2,3}$. Chronic marijuana use is associated with an increased risk of psychosis and depression ${ }^{4}$, and these relationships are even more concerning when use occurs during adolescence (for example, 5-7). In addition to the reported increased sensitivity of the adolescent period to the effects of marijuana, sex may also play a role in the consequences of both short- and long-term marijuana use with females more sensitive to depression and anxiety following marijuana exposure in adolescence ${ }^{8}$.

In addition to sex differences in the outcome of adolescent marijuana use, genetic background, including rat strain, can change the long-term consequences of THC exposure ${ }^{9,10}$. Rat strains vary on measures related to learning and memory ${ }^{11-18}$, anxiety $^{18}$ and development ${ }^{10}$ as well as in response to drugs of abuse ${ }^{19-25}$. Given that rat strains are used interchangeably in drug abuse research despite their innate differences, the inclusion of multiple strains of rat in any one study can help determine the strength and reproducibility of the long-term consequences of marijuana.

Marijuana use during adolescence may increase the likelihood of engaging in other physiologically and sociologically harmful drugs of abuse in adulthood. THC administration can potentiate the response to opioids ${ }^{26}$ and nicotine ${ }^{27}$, through the facilitation of brain reward mechanisms ${ }^{28,29}$. However, the interaction between the consumption of one drug of abuse and initiating use of another is complex, and individual differences may predict sensitivity to other drugs, including amphetamine ${ }^{19,23,30-32}$. The use of multiple rat strains, including Long-Evans (LER) and Wistar (WR) rats that have previously been observed to have differential sensitivity to THC, can model individual differences in response to THC.

This study sought to determine the long-term consequences of THC administration during the post-pubertal period in two previously studied strains of rats'. Following systemic administration of THC for 14 days after puberty onset, rats were aged to 90 days, at which point all rats were trained in a conditioned place preference (CPP) task to a subthreshold dose of d-amphetamine. It was hypothesized that if a particular strain and sex group was more sensitive to the effects of THC and if THC exposure increased the sensitivity to other drugs of abuse, sensitive rats would develop CPP to the sub-threshold dose of d-amphetamine and show increased neural activation, as inferred by protein expression of the immediate early gene, Cfos, in reward (nucleus accumbens) and context-specific (dorsal hippocampus) brain regions. However, if THC administration does not increase the sensitivity of rats to amphetamine, then no strain or sex group should show CPP behaviour in response to a subthreshold dose of d-amphetamine and no differences in Cfos expression should be observed.

\section{Methods}

Experiment 1: Determining a subthreshold dose of d-amphetamine in drug naïve rats

Subjects. Subjects were purchased and shipped from Charles River (Semmeville, Quebec) as adults (250-300g) (LER female: $\mathrm{N}=16$; LER male: $\mathrm{N}=24$; $\mathrm{WR}$ female: $\mathrm{N}=16$; $\mathrm{WR}$ male: $\mathrm{N}=16$ ). All rats were housed in standard laboratory conditions $\left(21^{\circ} \mathrm{C}\right.$ and $35 \%$ relative humidity; $\left.12 \mathrm{D}: 12 \mathrm{~L}\right)$ in Plexiglas tubs $(46 \mathrm{~cm} \times 25 \mathrm{~cm} \times 20 \mathrm{~cm})$ with ad libitum access to food and water. All rat handling and procedures were done in accordance to the University of Lethbridge's Animal Welfare Committee and the Canadian Council on Animal Care guidelines.

D-amphetamine doses. Drug naive adult rats were tested using three doses of d-amphetamine, $0.5 \mathrm{mg} / \mathrm{kg}$ and $0.7 \mathrm{mg} / \mathrm{kg}$ $(0.49 \mathrm{mg} / \mathrm{ml}$ d-amphetamine in saline, Sigma Aldrich). These doses were chosen as $1 \mathrm{mg} / \mathrm{kg}$ of $\mathrm{d}$-amphetamine has been shown to induce CPP in multiple research groups (as reviewed in 33) and was confirmed here in naïve LER male rats (Figure 1C). $\mathrm{N}=8$ for each strain, sex and drug dosage group.

CPP: Apparatus and training. Apparatus - A similar apparatus and procedure to that used for discriminative appetitive e $^{34,35}$ and fear conditioning ${ }^{36,37}$ to context tasks were implemented here. Briefly, opaque Plexiglas contexts that differed in shape (triangle versus square), colour (black versus white) and odour (amyl acetate versus eucalyptus), were connected with a grey alleyway. Both contexts and the alleyway were placed upon a clear Plexiglas table, and underneath the table, a mirror was inclined at a $45^{\circ}$ angle which allowed for viewing by both an observer and a video camera.

Training - Pre-exposure: Rats were placed in the grey alleyway and allowed to freely explore both contexts for 10min then returned to their home cage. Dwell time in each chamber was recorded by an observer.

Training: The context to be paired with d-amphetamine injection (paired) and the context to be paired with a saline injection (unpaired) were assigned to each rat in a counterbalanced, quasi-random fashion. For training, rats were given 6 consecutive daily exposures ${ }^{33}$, where they were given an injection of either saline or d-amphetamine then placed in one of the contexts for 30min. Injection type and context exposure alternated each day.

Preference: Rats explored the contexts connected by a grey alleyway for 10min. Dwell time in both contexts was recorded.

\section{Experiment 2: CPP in adolescent THC exposed rats}

Subjects, puberty onset and drug administration. Subjects were acquired, bred and handled as previously described ${ }^{9,10,15}$. Briefly, male and female LER and WR ( $N=9 /$ strain and sex group) were obtained from Charles River (Semmeville, Quebec). Rats acclimated for 2 weeks before breeding. Pups were 

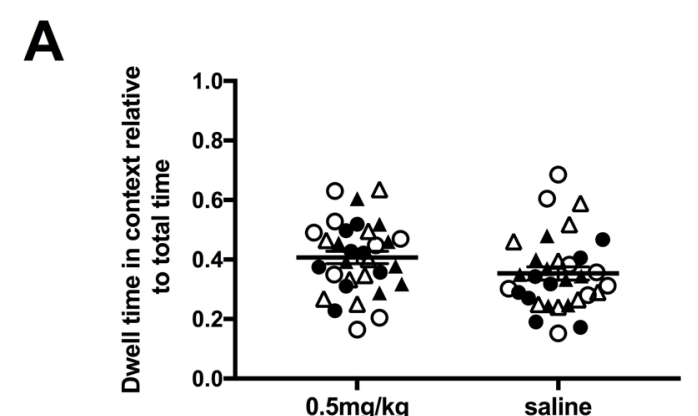

B

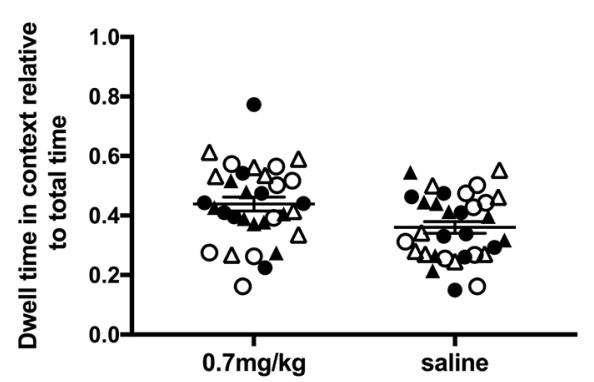

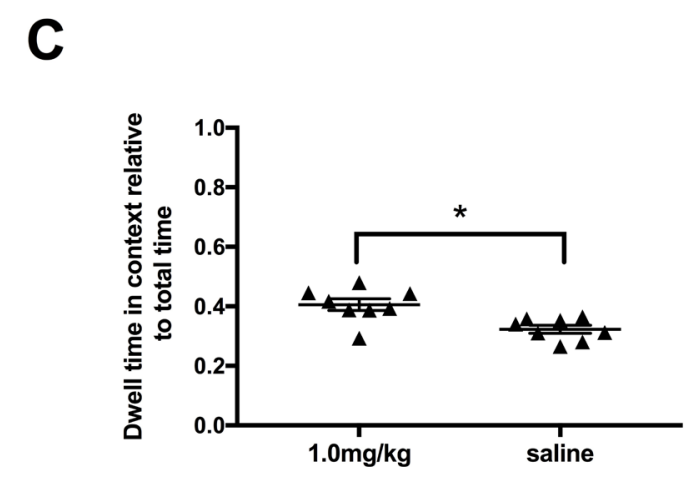

Figure 1. Dwell time in the previously paired (black) and unpaired (white) contexts during CPP. A. 0.5mg/kg d-amphetamine. B. $0.7 \mathrm{mg} / \mathrm{kg}$ d-amphetamine. C. $1.0 \mathrm{mg} / \mathrm{kg} \mathrm{d}$-amphetamine. Not e 0.5 and $0.7 \mathrm{mg} / \mathrm{kg} \mathrm{d}$-amphetamine was tested in all strain and sex groups and $1 \mathrm{mg} / \mathrm{kg}$ was tested only in LER males to confirm previously published work. ${ }^{*} p<0.05$. Individual data plus mean and SEE. LER females (closed circle), LER male (closed triangle), WR female (open circle), WR male (open triangle).

weaned at postnatal day 21 (p21) and placed into sex-matched pairs or triplets. $\mathrm{N}=8$ for all strain and sex groups for all experiments.

Puberty onset, group assignment and injection procedures were conducted as previously described ${ }^{10}$. Puberty onset was determined using the external features of the genitalia (vaginal opening and preputial separation), which correlate with gonadal hormone changes associated with puberty ${ }^{38,39}$. On weaning day, rats were assigned to their experimental groups: handled control (CON), vehicle (VEH; 1:1:18 ethanol:cremaphor:saline) or $5 \mathrm{mg} / \mathrm{kg}$ THC (THC). I.p. injection procedures and handling were conducted as previously described ${ }^{9}$. On the day of determination of puberty onset, rats were brought to a dark injection room. All rats were weighed before treatment. All rats received treatment for 14 consecutive days following determination of puberty onset. After the treatment period, rats were aged to adulthood (p90) before behavioural testing.

CPP to a subthreshold Dose of d-amphetamine: Apparatus \& training. From the results of Experiment 1 (see Results section), a subthreshold dose of d-amphetamine was determined to be $0.7 \mathrm{mg} / \mathrm{kg}$. This dose was used for all rats exposed to adolescent THC. Apparatus and training were conducted as described.

Perfusion \& fixation. Cfos protein is present in neurons that were active 20-30min after an experience ${ }^{40}$, and in rats, d-amphetamine will reach the brain within 5 min of an i.p. injection and remain stable for $1 \mathrm{hr}^{41}$. Any cfos protein signal detected $1 \mathrm{hr}$ after d-amphetamine injection represents the neurons active 30min after d-amphetamine injection. One week after the final day of CPP, rats were injected with a single $1 \mathrm{mg} / \mathrm{kg}$ dose of d-amphetamine and sat in their home cage for $1 \mathrm{hr}$. Rats were euthanized with a single i.p. injection of sodium pentobarbital $(120 \mathrm{mg} / \mathrm{kg})$ and transcardially perfused with approximately $150 \mathrm{~mL}$ of $1 \mathrm{x}$ phosphate-buffered saline (PBS) followed by $4 \%$ paraformaldehyde (PFA) in $1 \times$ PBS. Brains were immersion fixed in $4 \%$ PFA in $1 \times$ PBS. PFA was replaced $24 \mathrm{~h}$ after perfusion with $30 \%$ sucrose and $0.2 \% \mathrm{Na}$ azide in $1 \times \mathrm{xPS}$. Brains were sectioned at $40 \mu \mathrm{m}$ using a cryostat (CM1900, Leica, Germany) and placed directly into Eppendorf tubes containing $0.2 \% \mathrm{Na}$ azide in $1 \mathrm{xPBS}$. 
Cfos immunohistochemistry \& quantification. The amount of cfos protein was stained as previously described ${ }^{42}$. Briefly, free-floating tissue was washed (1xPBS), followed by a $30 \mathrm{~min}$ quenching step $\left(0.3 \% \mathrm{H}_{2} \mathrm{O}_{2}\right.$ in $\left.1 \mathrm{xPBS}\right)$. Tissue was blocked (1.5\% goat serum in $0.3 \%$ triton-X $1 \times \mathrm{XBS})$ for $30 \mathrm{~min}$ then incubated in $1^{\circ}$ antibody (rabbit; 1:1000, $0.33 \%$ triton-X in $1 \times$ PBS with $1.5 \%$ normal goat serum; Santa Cruz, California) for $24 \mathrm{hrs}$. Then, tissue was washed followed by a $24 \mathrm{hr}$ incubation in $2^{\circ}$ antibody (anti-rabbit; 1:1000, Vector Labs, Canada) at room temperature. On the third day, tissue was washed then placed in AB Complex (Vector labs, Canada) for $45 \mathrm{~min}$. Tissue was washed then bathed for $5 \mathrm{~min}$ in a $0.5 \%$ 3,3'-diaminobenzidine (DAB) solution (1xPBS with $\mathrm{NiCl}_{2}-6 \mathrm{H}_{2} \mathrm{O}$ and $0.05 \% \quad \mathrm{H}_{2} \mathrm{O}_{2}$ ). Sections were washed then mounted on $1 \%$ gelatin coated slides left to dry for $24 \mathrm{hrs}$, dehydrated and coverslipped with Permount.

Representative images from NAc and dorsal hippocampus were taken and quantified using particle analysis in Image $\mathbf{J}$ (NIH, USA). Regions of interest were defined using the Rat Brain Atlas ${ }^{43}$, and particles were counted per unit area.

Vaginal cytology and determination of estrous cycle

Vaginal cytology and the determination of estrous cycle was conducted as previously described ${ }^{9,10,34}$. Sterile Q-tips were dipped in sterile distilled water to collect samples onto standard glass slides (Vector labs, Canada). Vaginal smears were collected during all behavioural testing days and examined using brightfield microscopy on a Zeiss Axio Imager MT (Carl Zeiss, MicroImaging GmBH, Germany) using the 20X objective.

\section{Statistical analysis}

All raw data can be found in the raw dataset. Statistical tests were conducted using SPSS (IBM, ver 17), and estrous cycle phase was used as a covariate. For Experiment 1, a repeated measures ANOVA was conducted for percent dwell time in either context with strain and sex as the between subjects factors. Since we were interested in whether a preference for one context over another had occurred, a priori comparisons were conducted within each strain and sex group comparing dwell time in each context. We report partial $\eta^{2}$ for effect size and observed power for all results.

For Experiment 2, percent dwell time in the paired and unpaired contexts on the pre-exposure and preference days were compared within strain and sex groups using drug condition (group) as a between subjects factor. A priori hypotheses were established such that within each drug group and within each strain and sex group, comparisons between the paired and unpaired contexts were always conducted. For cfos quantification, between subjects comparisons within strain and sex groups were conducted in order to determine the effects of drug exposure on a specific strain and sex group.

\section{Results}

Estrous cycle did not significantly alter any of the results and was not included as a covariate in subsequent analyses.

\section{Experiment 1: Determination of a subthreshold dose of d-amphetamine}

No initial preference nor any preference after training was observed for 0.5 (Figure $1 \mathrm{~A}$ ) or $0.7 \mathrm{mg} / \mathrm{kg}$ (Figure 1B) of d-amphetamine for any strain or sex group (see Table 1 for statistical results). A dose of $1 \mathrm{mg} / \mathrm{kg}$ d-amphetamine was used to confirm previous experiments and did induce significant place preference (see Figure 1C), thus $0.7 \mathrm{mg} / \mathrm{kg}$ dose was considered subthreshold for all subsequent experiments.

\section{Experiment 2: CPP to a sub-threshold dose of d-amphetamine}

There were no pre-existing bias to spend more time in the paired or unpaired context, regardless of strain, sex or drug administration. No interaction between drug or context were observed in any strain and sex group. On the preference day, LER females overall spent significantly more time in the paired context $\left(\mathrm{F}_{(1,21)}=17.483, \mathrm{p}<0.001\right.$; Figure $\left.2 \mathrm{~A}\right)$. No overall effect of group was observed. Individual comparisons within groups revealed that CON $(\mathrm{p}=0.04)$ and VEH $(\mathrm{p}=0.028)$ LER females spent significantly more time in the context paired with d-amphetamine. No such difference was observed within LER females exposed to THC, although this value did approach statistical significance $(p=0.065)$. LER males (Figure 2B), WR females (Figure 2C) and WR males (Figure 2D) showed no significant effect of drug as well as did not show an overall preference for one context over the others (see Table 2 for statistical results).

\section{Cfos immunohistochemistry}

No significant effects were observed for any strain and sex group for cfos expression in dorsal hippocampus (Figure 3) and NAc (Figure 4) following a $1 \mathrm{mg} / \mathrm{kg}$ injection of d-amphetamine.

Dataset 1. Raw data associated with Figure 1 - Figure 4

http://dx.doi.org/10.5256/f1000research.14029.d196720 
A

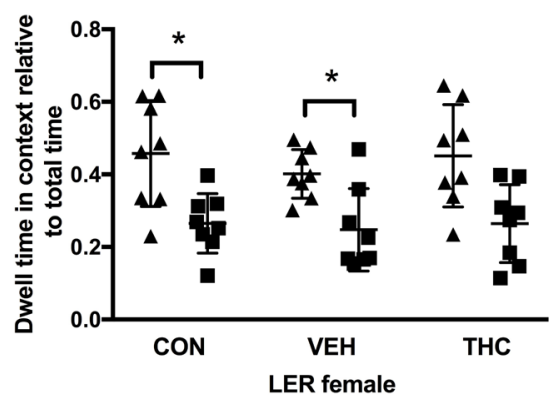

C

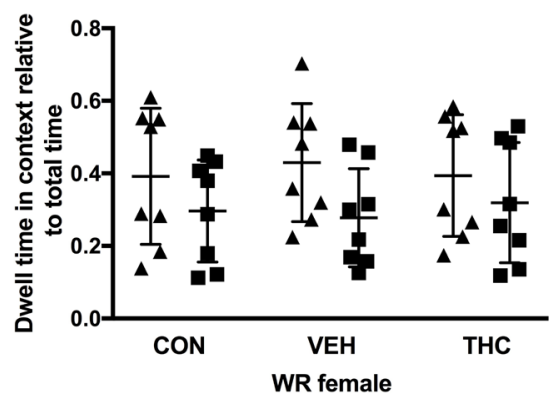

B

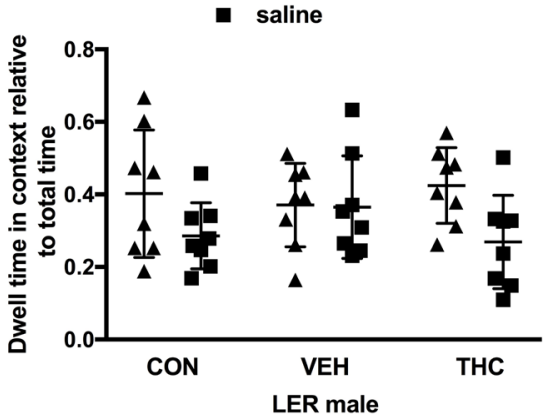

D

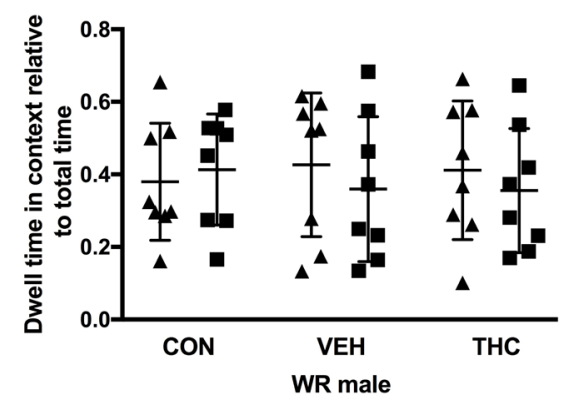

Figure 2. CPP to $0.7 \mathrm{mg} / \mathbf{k g}$ d-amphetamine in THC exposed adolescent LER and WR male and female rats. Preference for A) LER females, B) LER males, C) WR females and D) WR males. ${ }^{*} p<0.05$.

A

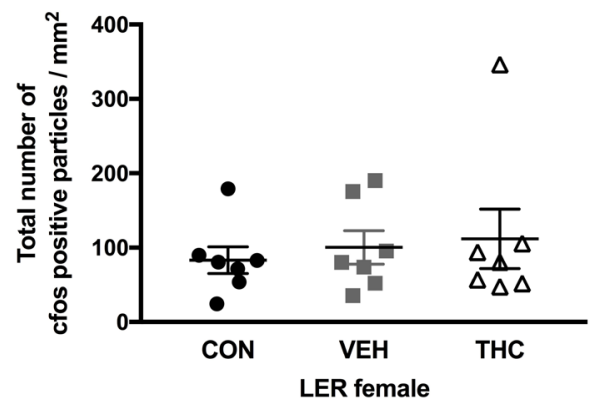

C

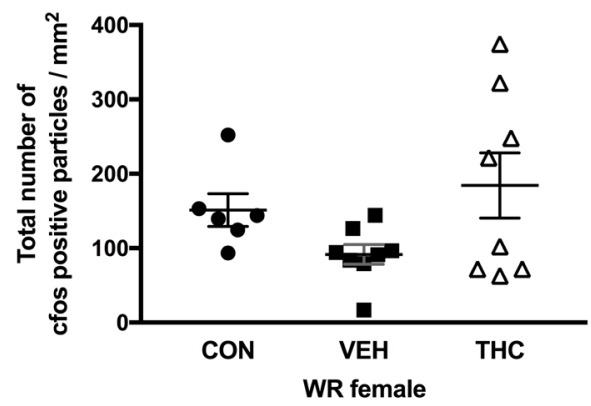

B

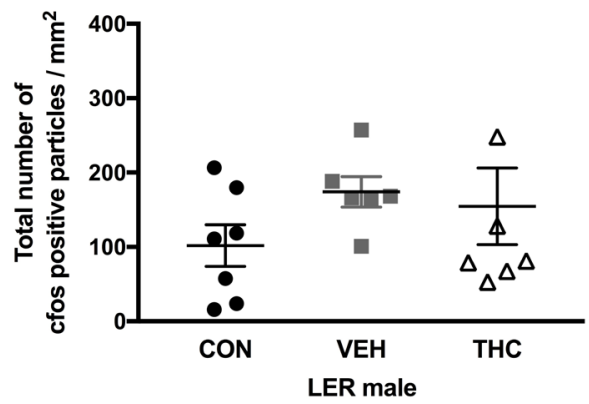

D

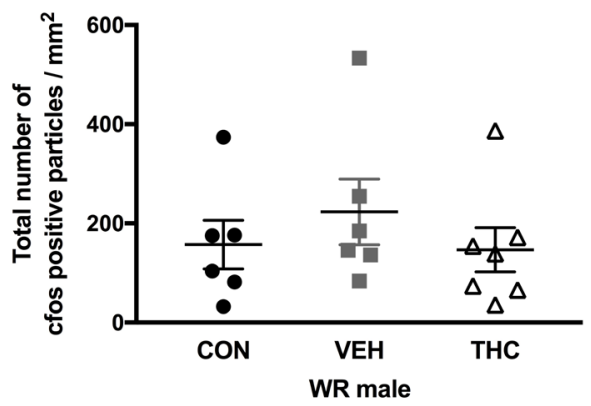

Figure 3. Cfos staining in dorsal hippocampus in LER and WR male and female rats exposed to THC as adolescents. 
A

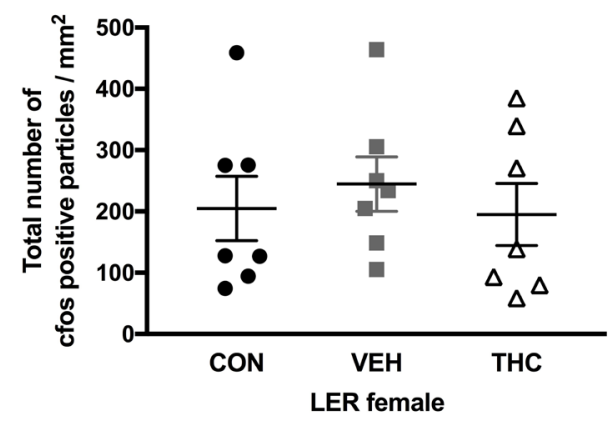

C

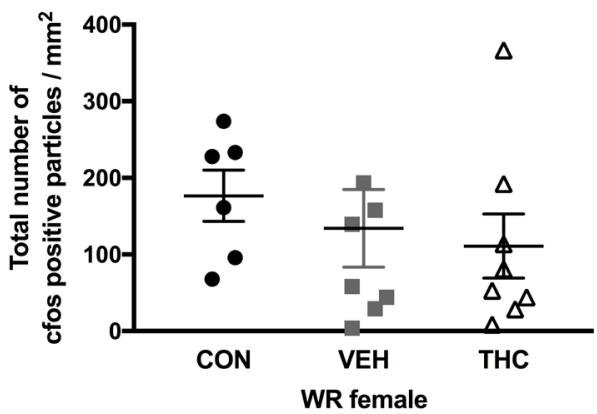

B

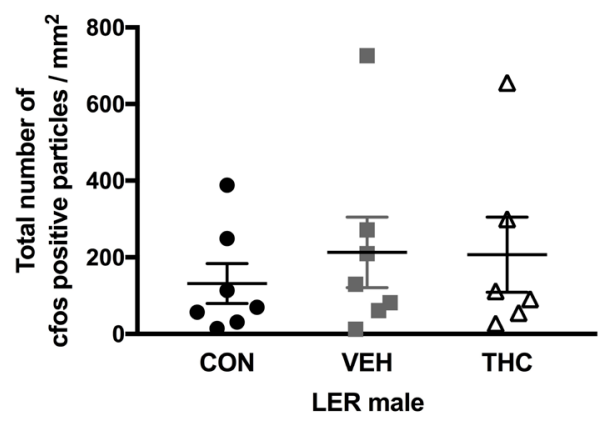

D

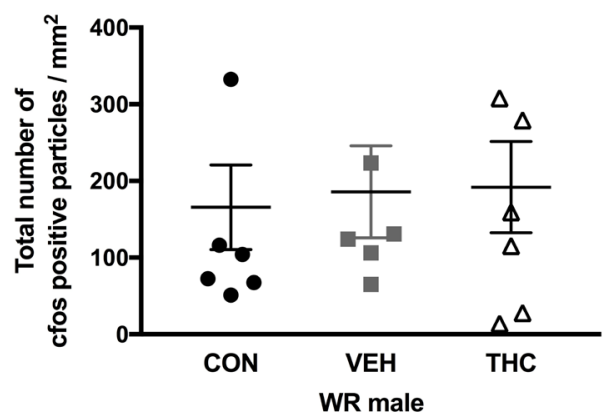

Figure 4. Cfos staining in NAc in LER and WR male and female rats exposed to THC as adolescents.

\section{Discussion}

Here, we report no long-term consequences of adolescent THC exposure on sensitivity to d-amphetamine in adulthood. We did observe that rearing environment affected sensitivity to d-amphetamine in LER females; CON LER females bred in house expressed CPP behaviour to a $0.7 \mathrm{mg} / \mathrm{kg}$ dose of d-amphetamine, whereas those obtained from a commercial breeder (Charles River) did not. Additionally, using immediate early gene protein expression, we observed no significant effect of THC exposure following puberty onset in nucleus accumbens and dorsal hippocampus d-amphetamine-induced activation.

\section{No effect of THC}

Adolescent THC exposure did not potentiate the adult response to d-amphetamine. D-amphetamine increases dopaminergic tone when systemically administered ${ }^{44-47}$ and is highly rewarding ${ }^{48,49}$. Given the premise that THC acts as a gateway drug, we assumed adolescent exposure to THC would potentiate reward circuitry, enhancing sensitivity to d-amphetamine.

Priming of amphetamine response by cannabinoids has been observed by some researchers ${ }^{50-52}$ and not others ${ }^{53}$. Differences between among studies look for this effect include the dose, duration and starting age of exposure to THC as well as the timing of exposure to amphetamine, which one study reported amphetamine-primed reward to be dependent on the time since exposure to $\mathrm{THC}^{51}$. However, our results should help mitigate many of these issues, as our dose of THC was relatively moderate, was given following the onset of puberty, which can be influenced by $\mathrm{THC}^{54}$ and lasted throughout the adolescent period and in to early adulthood, all of which are reasonable analogues, given experimental constraints, to the human adolescent marijuana consumption experience. One possible explanation for the pattern of results obtained in the present study may be the use of CPP versus the self-administration paradigm. CPP is a standard metric for determining the rewarding properties of drugs of abuse and has been observed for multiple doses of drugs, including amphetamine ${ }^{33,55-57}$. Future experiments should consider allowing animals to self-administer either THC or amphetamines, potentially looking at the correlations between self-administration of both drugs. Unfortunately, THC has proven problematic in self-administration paradigms in 55,58,59.

Previous studies have demonstrated priming effects of THC to other drugs of abuse. Increased self-administration of heroin or other opiates has been observed ${ }^{52,60-62}$, partially dependent on cannabinoid receptors ${ }^{63}$. Thus, the endogenous opioid system is particularly sensitive to the long-term consequences of THC. Indeed, given the increased abuse of prescription opiates, research examining the interplay between the endogenous cannabinoid 
and opioid systems could potentially prevent the transition of using marijuana to opiates. It is possible that priming of THC is specific to drugs targeting the opioid system.

\section{Effect of rearing environment}

LER females bred in house at the University of Lethbridge expressed CPP to a $0.7 \mathrm{mg} / \mathrm{kg}$ dose of d-amphetamine whereas those purchased from Charles River did not. This was exclusively observed in LER females. Strain differences in response to amphetamine have been observed previously ${ }^{19,20,22,23}$. This strain and sex specific effect in response to amphetamine may be the result of the interplay between the stress system and monoaminergic function, which has been posited to explain differences in response to amphetamine between two other strains of rats, Fisher 344 and Lewis ${ }^{64,65}$. It is possible that differences in these systems may occur in LER females reared under different conditions ${ }^{66,67}$. Regardless, further understanding of this fascinating effect of strain and rearing conditions should be explored as it is clear that genetic and differences in rearing correlate highly with drug abuse in adulthood ${ }^{21,32,68-70}$.

Strain-dependent sex difference in response to amphetamines has been observed previously ${ }^{64}$, although this effect was not observed in LER. Differential responses in one sex and not the other across strains are not uncommon (for example, 71), however most studies examining strain differences in response to drugs of abuse typically only use males (as discussed in 64). There is a tendency for females to be more sensitive to drugs of abuse, including amphetamine ${ }^{30,64,72-75}$, which is partially mediated through the endogenous hormonal rhythms of females ${ }^{76-78}$. Here, training days covered the extent of at least one full estrous cycle, and there was no significant effect of estrous cycle phase on CPP behaviour. Thus, we have identified that LER females are sensitive to rearing environment in relation to CPP behaviour in response to amphetamine. This kind of effect should not be underestimated as the implications of ignoring sex, strain, rearing differences and their interactions in research are being increasingly recognized by granting agencies and scientific organizations to contribute to individual differences and reproducibility in current neuroscience research.

\section{Conclusions}

This study does not support a link between adolescent THC exposure and sensitivity to other drugs of abuse, where rats were tested for changes in sensitivity to $\mathrm{d}$-amphetamine following long-term exposure of THC during adolescence. This is surprising, given the vulnerability of LER females to developmental perturbations (in this case, rearing environment) on d-amphetamine CPP. WR displayed stable behavioural profiles; neither rearing environment nor THC administration altered their response to a sub-threshold dose of d-amphetamine. Our previous research identified WR as resilient to the effects of adolescent THC exposure9. Further research into discovering the mechanisms behind resiliency in these groups may help identify mechanisms that can be protective for groups at-risk to the development of addiction.

Data availability

Dataset 1: Raw data associated with Figure 1-Figure 4. 10.5256/ f1000research.14029.d19672079

Competing interests

The authors declare that there are no competing interests.

\section{Grant information}

This research was funded by a NSERC Discovery Grant awarded to RJM.

The funders had no role in study design, data collection and analysis, decision to publish, or preparation of the manuscript.
1. UN Office on Drugs and Crime (UNODC): World Drug Report 2015. 2015 Reference Source

2. Mechoulam R: Marihuana chemistry. Science. 1970; 168(3936): 1159-1165. PubMed Abstract | Publisher Full Text

3. Razdan RK: Structure-activity relationships in cannabinoids. Pharmacol Rev. 1986; 38(2): 75-149.

PubMed Abstract

4. Moore TH, Zammit S, Lingford-Hughes A, et al.: Cannabis use and risk of psychotic or affective mental health outcomes: a systematic review. Lancet 2007; 370(9584): 319-328

PubMed Abstract | Publisher Full Text

5. Cha YM, Jones $\mathrm{KH}$, Kuhn CM, et al: Sex differences in the effects of delta ${ }^{9}$ tetrahydrocannabinol on spatial learning in adolescent and adult rats. Behav Pharmacol. 2007; 18(5-6): 563-569. PubMed Abstract | Publisher Full Tex

6. Cha YM, White AM, Kuhn CM, et al: Differential effects of delta9-THC on learning in adolescent and adult rats. Pharmacol Biochem Behav. 2006; 83(3): $448-455$

PubMed Abstract | Publisher Full Text
7. O'Shea M, Singh ME, McGregor IS, et al: Chronic cannabinoid exposure produces lasting memory impairment and increased anxiety in adolescent but not adult rats. J Psychopharmacol. 2004; 18(4): 502-508. PubMed Abstract | Publisher Full Text

8. Patton GC, Coffey $C$, Carlin JB, et al:: Cannabis use and mental health in young people: cohort study. BMJ. 2002; 325(7374): 1195-1198. PubMed Abstract | Publisher Full Text | Free Full Text

9. Keeley RJ, Trow J, Bye C, et al.: Part II: Strain- and sex-specific effects of adolescent exposure to THC on adult brain and behaviour: variants of learning, anxiety and volumetric estimates. Behav Brain Res. 2015; 288: 132-52. PubMed Abstract | Publisher Full Text

10. Keeley RJ, Trow J, McDonald RJ: Strain and sex differences in puberty onset and the effects of THC administration on weight gain and brain volumes. Neuroscience. 2015; 305: 328-42. PubMed Abstract | Publisher Full Text

11. Andrews JS, Jansen JH, Linders S, et al:: Performance of four different rat strains in the autoshaping, two-object discrimination, and swim maze tests of learning and memory. Physiol Behav. 1995; 57(4): 785-790. PubMed Abstract | Publisher Full Text 
12. Holahan MR, Honegger KS, Routtenberg A: Expansion and retraction of hippocampal mossy fibers during postweaning development: strain-specific effects of NMDA receptor blockade. Hippocampus. 2007; 17(1): 58-67. PubMed Abstract | Publisher Full Text

13. Holahan MR, Rekart JL, Sandoval J, et al:: Spatial learning induces presynaptic structural remodeling in the hippocampal mossy fiber system of two rat strains. Hippocampus. 2006; 16(6): 560-570. PubMed Abstract | Publisher Full Text

14. Hort J, Brozek $\mathrm{G}$, Komárek $\mathrm{V}$, et al.: Interstrain differences in cognitive functions in rats in relation to status epilepticus. Behav Brain Res. 2000; 112(1-2): 77-83. PubMed Abstract | Publisher Full Text

15. Keeley RJ, Bye C, Trow J, et al:: Strain and sex differences in brain and behaviour of adult rats: Learning and memory, anxiety and volumetric estimates. Behav Brain Res. 2015; 288(5): 118-31. PubMed Abstract | Publisher Full Text

16. Keeley RJ, Wartman BC, Häusler AN, et al:: Effect of juvenile pretraining on adolescent structural hippocampal attributes as a substrate for enhanced spatial performance. Learn Mem. 2010; 17(7): 344-354.

PubMed Abstract | Publisher Full Text

17. Paré WP: Enhanced retrieval of unpleasant memories influenced by shock controllability, shock sequence, and rat strain. Biol Psychiatry. 1996; 39(9): 808-813.

PubMed Abstract | Publisher Full Text

18. van der Staay FJ, Schuurman T, van Reenen CG, et al:: Emotional reactivity and cognitive performance in aversively motivated tasks: a comparison between four rat strains. Behav Brain Funct. 2009; 5: 50. PubMed Abstract | Publisher Full Text | Free Full Text

19. Anisman H, Cygan D: Central effects of scopolamine and (+)-amphetamine on locomotor activity: interaction with strain and stress variables. Neuropharmacology. 1975; 14(11): 835-840.

PubMed Abstract | Publisher Full Text

20. Camp DM, Browman KE, Robinson TE: The effects of methamphetamine and cocaine on motor behavior and extracellular dopamine in the ventral striatum of Lewis versus Fischer 344 rats. Brain Res. 1994; 668(1-2): 180-193. PubMed Abstract | Publisher Full Text

21. Deiana S, Fattore L, Spano MS, et al.: Strain and schedule-dependent differences in the acquisition, maintenance and extinction of intravenous cannabinoid self-administration in rats. Neuropharmacology. 2007; 52(2): 646-654. PubMed Abstract | Publisher Full Text

22. Fujimoto $\mathrm{Y}$, Kitaichi $\mathrm{K}$, Nakayama $\mathrm{H}$, et al:: The pharmacokinetic properties of methamphetamine in rats with previous repeated exposure to methamphetamine: the differences between Long-Evans and Wistar rats. Exp Anim. 2007; 56(2): 119-129.

PubMed Abstract | Publisher Full Tex

23. George FR, Porrino LJ, Ritz MC, et al.: Inbred rat strain comparisons indicate different sites of action for cocaine and amphetamine locomotor stimulant effects. Psychopharmacology (Berl). 1991; 104(4): 457-462.

PubMed Abstract | Publisher Full Text

24. Onaivi ES, Maguire PA, Tsai NF, et al.: Comparison of behavioral and central BDZ binding profile in three rat lines. Pharmacol Biochem Behav. 1992; 43(3): 825-831.

PubMed Abstract | Publisher Full Text

25. Ortiz S, Oliva JM, Pérez-Rial S, et al.: Differences in basal cannabinoid CB receptor function in selective brain areas and vulnerability to voluntary alcohol consumption in Fawn Hooded and Wistar rats. Alcohol Alcohol. 2004 39(4): 297-302.

PubMed Abstract | Publisher Full Text

26. Fiellin LE, Tetrault JM, Becker WC, et al:: Previous use of alcohol, cigarettes, and marijuana and subsequent abuse of prescription opioids in young adults. J Adolesc Health. 2013; 52(2): 158-163.

PubMed Abstract | Publisher Full Text | Free Full Text

27. Panlilio LV, Zanettini C, Barnes C, et al.: Prior exposure to THC increases the addictive effects of nicotine in rats. Neuropsychopharmacology. 2013; 38(7): 1198-1208.

PubMed Abstract | Publisher Full Text | Free Full Text

28. Gardner EL: Addictive potential of cannabinoids: the underlying neurobiology Chem Phys Lipids. 2002; 121(1-2): 267-290.

PubMed Abstract | Publisher Full Tex

29. Gardner EL, Paredes W, Smith D, et al:: Facilitation of brain stimulation reward by delta9-tetrahydrocannabinol. Psychopharmacology (Berl). 1988; 96(1): 142-144. PubMed Abstract | Publisher Full Text

30. Klebaur JE, Bevins RA, Segar TM, et al: Individual differences in behavioral responses to novelty and amphetamine self-administration in male and female rats. Behav Pharmacol. 2001; 12(4): 267-275. PubMed Abstract | Publisher Full Text

31. Piazza PV, Deminiere JM, Le Moal M, et al:: Factors that predict individual vulnerability to amphetamine self-administration. Science. 1989; 245(4925): 1511-1513.

PubMed Abstract | Publisher Full Text

32. Schenk S, Hunt T, Malovechko R, et al.: Differential effects of isolation housing on the conditioned place preference produced by cocaine and amphetamine. Pharmacol Biochem Behav. 1986; 24(6): 1793-1796.

PubMed Abstract | Publisher Full Text
33. Tzschentke TM: Measuring reward with the conditioned place preference (CPP) paradigm: update of the last decade. Addict Biol. 2007; 12(3-4): 227-462. PubMed Abstract | Publisher Full Text

34. Keeley RJ, Zelinski EL, Fehr L, et al:: The effect of exercise on carbohydrate preference in female rats. Brain Res Bull. 2014; 101: 45-50.

PubMed Abstract | Publisher Full Text

35. Ralph MR, $\mathrm{Ko} \mathrm{CH}$, Antoniadis $\mathrm{EA}$, et al:: The significance of circadian phase fo performance on a reward-based learning task in hamsters. Behav Brain Res. 2002; 136(1): 179-184.

PubMed Abstract | Publisher Full Text

36. Antoniadis EA, McDonald RJ: Discriminative fear conditioning to context expressed by multiple measures of fear in the rat. Behav Brain Res. 1999; 101(1): 1-13.

PubMed Abstract | Publisher Full Tex

37. Antoniadis $\mathrm{EA}, \mathrm{Ko} \mathrm{CH}$, Ralph $\mathrm{MR}$, et al.: Circadian rhythms, aging and memory. Behav Brain Res. 2000; 114(1-2): 221-233. PubMed Abstract | Publisher Full Text

38. Korenbrot CC, Huhtaniemi IT, Weiner RI: Preputial separation as an external sign of pubertal development in the male rat. Biol Reprod. 1977; 17(2): 298-303. PubMed Abstract | Publisher Full Text

39. Parker CR Jr, Mahesh VB: Hormonal events surrounding the natural onset of puberty in female rats. Biol Reprod. 1976; 14(3): 347-353. PubMed Abstract | Publisher Full Tex

40. Hu E, Mueller E, Oliviero S, et al.: Targeted disruption of the c-fos gene demonstrates $c$-fos-dependent and -independent pathways for gene expression stimulated by growth factors or oncogenes. EMBO J. 1994; 13(13): 3094-103.

PubMed Abstract | Free Full Text

41. Kuhn CM, Schanberg SM: Metabolism of amphetamine after acute and chronic administration to the rat. J Pharmacol Exp Ther. 1978; 207(2): 544-554. PubMed Abstract

42. Blum ID, Lamont EW, Rodrigues T, et al:: Isolating neural correlates of the pacemaker for food anticipation. PLoS One. 2012; 7(4): e36117. PubMed Abstract | Publisher Full Text | Free Full Text

43. Paxinos G, Watson C: The rat brain in stereotaxic coordinates. Academic press;

Reference Source

44. Melega WP, Williams AE, Schmitz DA, et al.: Pharmacokinetic and pharmacodynamic analysis of the actions of D-amphetamine and D-methamphetamine on the dopamine terminal. J Pharmacol Exp Ther. 1995; 274(1): 90-96 PubMed Abstract

45. Sulzer D, Maidment NT, Rayport S: Amphetamine and other weak bases act to promote reverse transport of dopamine in ventral midbrain neurons. $J$ Neurochem. 1993; 60(2): 527-535. PubMed Abstract | Publisher Full Text

46. Sulzer D, Sonders MS, Poulsen NW, et al:: Mechanisms of neurotransmitter release by amphetamines: a review. Prog Neurobiol. 2005; 75(6): 406-433. PubMed Abstract | Publisher Full Text

47. Taylor KM, Snyder SH: Amphetamine: differentiation by $\mathrm{d}$ and $\mathrm{I}$ isomers of behavior involving brain norepinephrine or dopamine. Science. 1970; 168(3938): 1487-1489.

PubMed Abstract | Publisher Full Text

48. Pickens R, Harris WC: Self-administration of d-amphetamine by rats. Psychopharmacologia. 1968; 12(2): 158-163.

PubMed Abstract | Publisher Full Text

49. Yokel RA, Wise RA: Increased lever pressing for amphetamine after pimozide in rats: implications for a dopamine theory of reward. Science. 1975; 187(4176): 547-549.

PubMed Abstract | Publisher Full Text

50. Gorriti MA, Rodriguez de Fonseca F, Navarro M, et al.: Chronic (-)-delta9tetrahydrocannabinol treatment induces sensitization to the psychomotor effects of amphetamine in rats. Eur J Pharmacol. 1999; 365(2-3): 133-142. PubMed Abstract | Publisher Full Text

51. Lamarque S, Taghzouti K, Simon H: Chronic treatment with Delta ${ }^{9}$ tetrahydrocannabinol enhances the locomotor response to amphetamine and heroin. Implications for vulnerability to drug addiction. Neuropharmacology. 2001; 41(1): 118-129. PubMed Abstract | Publisher Full Text

52. Pryor GT, Larsen FF, Husain S, et al:: Interactions of delta9-tetrahydrocannabinol with d-amphetamine, cocaine, and nicotine in rats. Pharmacol Biochem Behav. 1978; 8(3): 295-318.

PubMed Abstract | Publisher Full Text

53. Arnold JC, Topple AN, Hunt GE, et al:: Effects of pre-exposure and coadministration of the cannabinoid receptor agonist CP 55,940 on behavioral sensitization to cocaine. Eur J Pharmacol. 1998; 354(1): 9-16. PubMed Abstract | Publisher Full Text

54. Wenger T, Croix D, Tramu G: The effect of chronic prepubertal administration of marihuana (delta-9-tetrahydrocannabinol) on the onset of puberty and the postpubertal reproductive functions in female rats. Biol Reprod. 1988; 39(3) 540-545.

PubMed Abstract | Publisher Full Text 
55. Braida D, losuè S, Pegorini S, et al.: Delta9-tetrahydrocannabinol-induced conditioned place preference and intracerebroventricular self-administration in rats. Eur J Pharmacol. 2004; 506(1): 63-69. PubMed Abstract | Publisher Full Text

56. Maldonado R, Rodriguez de Fonseca F: Cannabinoid addiction: behavioral models and neural correlates. J Neurosci. 2002; 22(9): 3326-3331. PubMed Abstract

57. Zangen A, Solinas M, Ikemoto S, et al:: Two brain sites for cannabinoid reward. J Neurosci. 2006; 26(18): 4901-4907. PubMed Abstract | Publisher Full Tex

58. Takahashi RN, Singer G: Self-administration of delta ${ }^{9}$-tetrahydrocannabinol by rats. Pharmacol Biochem Behav. 1979; 11(6): 737-740. PubMed Abstract | Publisher Full Text

59. Tanda G, Munzar P, Goldberg SR: Self-administration behavior is maintained by the psychoactive ingredient of marijuana in squirrel monkeys. Nat Neurosci. 2000; 3(11): 1073-1074 PubMed Abstract | Publisher Full Text

60. Cadoni C, Pisanu A, Solinas M, et al.: Behavioural sensitization after repeated exposure to Delta 9-tetrahydrocannabinol and cross-sensitization with morphine. Psychopharmacology (Berl). 2001; 158(3): 259-266. PubMed Abstract | Publisher Full Text

61. Ellgren M, Spano SM, Hurd YL: Adolescent cannabis exposure alters opiate intake and opioid limbic neuronal populations in adult rats. Neuropsychopharmacology. 2007; 32(3): 607-615. PubMed Abstract | Publisher Full Text

62. Vela G, Fuentes JA, Bonnin A, et al.: Perinatal exposure to delta9tetrahydrocannabinol (delta9-THC) leads to changes in opioid-related behavioral patterns in rats. Brain Res. 1995; 680(1-2): 142-147. PubMed Abstract | Publisher Full Text

63. Ledent C, Valverde O, Cossu G, et al:: Unresponsiveness to cannabinoids and reduced addictive effects of opiates in CB1 receptor knockout mice. Science. 1999; 283(5400): 401-404

PubMed Abstract | Publisher Full Text

64. Kosten TA, Ambrosio E: HPA axis function and drug addictive behaviors: insights from studies with Lewis and Fischer 344 inbred rats. Psychoneuroendocrinology. 2002; 27(1-2): 35-69. PubMed Abstract | Publisher Full Text

65. Wu HH, Wang S: Strain differences in the chronic mild stress animal model of depression. Behav Brain Res. 2010; 213(1): 94-102. PubMed Abstract | Publisher Full Text

66. Henry C, Kabbaj M, Simon H, et al.: Prenatal stress increases the hypothalamopituitary-adrenal axis response in young and adult rats. $J$ Neuroendocrinol. 1994; 6(3): 341-5.

PubMed Abstract | Publisher Full Text

67. Muneoka K, Mikuni M, Ogawa T, et al.: Prenatal dexamethasone exposure alters brain monoamine metabolism and adrenocortical response in rat offspring.
Am J Physiol. 1997; 273(5 Pt 2): R1669-1675. PubMed Abstract | Publisher Full Text

68. Meaney MJ, Brake W, Gratton A: Environmental regulation of the development of mesolimbic dopamine systems: a neurobiological mechanism for vulnerability to drug abuse? Psychoneuroendocrinology. 2002; 27(1-2): 127-38. PubMed Abstract | Publisher Full Text

69. Stairs DJ, Bardo MT: Neurobehavioral Effects of Environmental Enrichment and Drug Abuse Vulnerability. Pharmacol Biochem Behav. 2009; 92(3): 377-82. PubMed Abstract | Publisher Full Text | Free Full Text

70. Schenk S, Lacelle G, Gorman K, et al.: Cocaine self-administration in rats influenced by environmental conditions: implications for the etiology of drug abuse. Neurosci Lett. 1987; 81(1-2): 227-31.

PubMed Abstract | Publisher Full Text

71. Stöhr T, Schulte Wermeling D, Weiner I, et al.: Rat strain differences in openfield behavior and the locomotor stimulating and rewarding effects of amphetamine. Pharmacol Biochem Behav. 1998; 59(4): 813-818. PubMed Abstract | Publisher Full Text

72. Beatty WW, Holzer GA: Sex differences in stereotyped behavior in the rat Pharmacol Biochem Behav. 1978; 9(6): 777-783. PubMed Abstract | Publisher Full Text

73. Compton DR, Johnson KM: Effects of acute and chronic clozapine and haloperidol on in vitro release of acetylcholine and dopamine from striatum and nucleus accumbens. $J$ Pharmacol Exp Ther. 1989; 248(2): 521-530. PubMed Abstract

74. Savageau MM, Beatty WW: Gonadectomy and sex differences in the behavioral responses to amphetamine and apomorphine of rats. Pharmacol Biochem Behav. 1981; 14(1): 17-21.

PubMed Abstract | Publisher Full Text

75. Tseng $A H$, Craft RM: Sex differences in antinociceptive and motoric effects of cannabinoids. Eur J Pharmacol. 2001; 430(1): 41-47. PubMed Abstract | Publisher Full Text

76. Becker JB: Estrogen rapidly potentiates amphetamine-induced striatal dopamine release and rotational behavior during microdialysis. Neurosci Lett. 1990; 118(2): 169-171.

PubMed Abstract | Publisher Full Text

77. Becker JB, Beer ME: The influence of estrogen on nigrostriatal dopamine activity: behavioral and neurochemical evidence for both pre- and postsynaptic components. Behav Brain Res. 1986; 19(1): 27-33. PubMed Abstract | Publisher Full Text

78. Peris J, Decambre N, Coleman-Hardee ML, et al: Estradiol enhances behavioral sensitization to cocaine and amphetamine-stimulated striatal [3H]dopamine release. Brain Res. 1991; 566(1-2): 255-264. PubMed Abstract | Publisher Full Text

79. Keeley RJ, Bye C, Trow J, et al: Dataset 1 in: Adolescent THC exposure does not sensitize conditioned place preferences to subthreshold d-amphetamine in male and female rats. F1000Research. 2018. Data Source 


\section{Open Peer Review}

\section{Current Peer Review Status:}

\section{Version 1}

Reviewer Report 25 April 2018

https://doi.org/10.5256/f1000research.15248.r32202

(C) 2018 Khokhar J. This is an open access peer review report distributed under the terms of the Creative Commons Attribution License, which permits unrestricted use, distribution, and reproduction in any medium, provided the original work is properly cited.

\section{Jibran Y. Khokhar}

University of Guelph, Guelph, ON, Canada

This report by Keeley et al., examines the effects of adolescent THC exposure on conditioned place preference for d-amphetamine. While no effects of adolescent THC exposure were found on the CPP or the neural correlates (c-fos expression), the authors' inclusion of important factors such as strain and sex make this an important study to consider for those interested in studying the effects of developmental cannabinoid exposure on future risk for substance use. Suggested changes would help to improve the impact of this paper.

\section{Abstract:}

Last Sentence: include "sub-threshold dose of" before d-amphetamine

Introduction:

The introduction begins with mentions of psychosis, anxiety and depression, whereas the central questions being asked in this study are not related to those topics. The authors should think about setting the research question in the opening paragraph.

Methods:

Subjects: This section is unclear. Are the subjects being referred to here the parents of the rats used in the study?

D-Amphetamine Doses: $1 \mathrm{mg} / \mathrm{kg}$ not listed here

Statistical Analyses: Unclear whether dwell times were also compared within-animal preand post-training?

Results:

Tables missing, but mentioned in the text.

Discussion:

Since the authors chose to discuss psychosis in the introduction, maybe they can discuss it in the context of the null results of d-amphetamine on c-fos expression, since an 
accentuated response to amphetamine is something that is seen in patients with schizophrenia.

An excellent review by Chadwick and Hurd ${ }^{1}$ might help to formulate some of these thoughts.

Rearing environment was not one of the research objectives/hypotheses and the relevance to this discussion needs to be strengthened.

\section{References}

1. Chadwick B, Miller ML, Hurd YL: Cannabis Use during Adolescent Development: Susceptibility to Psychiatric Illness.Front Psychiatry. 2013; 4: 129 PubMed Abstract | Publisher Full Text

Is the work clearly and accurately presented and does it cite the current literature? Yes

Is the study design appropriate and is the work technically sound?

Yes

Are sufficient details of methods and analysis provided to allow replication by others? Yes

If applicable, is the statistical analysis and its interpretation appropriate? Yes

Are all the source data underlying the results available to ensure full reproducibility? Yes

Are the conclusions drawn adequately supported by the results?

Yes

Competing Interests: No competing interests were disclosed.

I confirm that I have read this submission and believe that I have an appropriate level of expertise to confirm that it is of an acceptable scientific standard.

Author Response 10 Sep 2018

Robin Keeley, University of Lethbridge, 4401 University Drive, Lethbridge, Canada

We would like to thank the Referee for their thoughtful comments on our research. We have specifically addressed all comments that you mentioned and further clarified any statements as required. Specifically, we found your insight on the topic of schizophrenia particularly interesting. We believe that if this research study had been conducted in an animal model of schizophrenia, the results may have been significantly different.

Thank you again. 
Best,

Robin J. Keeley

Competing Interests: No competing interests were disclosed.

Reviewer Report 04 April 2018

https://doi.org/10.5256/f1000research.15248.r32404

(c) 2018 McLaughlin R et al. This is an open access peer review report distributed under the terms of the Creative Commons Attribution License, which permits unrestricted use, distribution, and reproduction in any medium, provided the original work is properly cited.

\section{Ryan J. McLaughlin}

Department of Integrative Physiology \& Neuroscience, Translational Addiction Research Center, Washington State University, Pullman, WA, USA

\section{Timothy G. Freels}

Department of Psychology, University of Memphis, Memphis, TN, USA

This article contributes valuable insight into issues that are commonly observed in literature regarding the impact of adolescent $\Delta^{9}$-tetrahydrocannabinol (THC) exposure on future drugseeking behavior. Particularly, careful attention is directed towards the influence of sex (including estrous cycle) and animal strain on modulation of drug-seeking behavior by adolescent THC administration. These crucial factors likely contribute to conflicting findings reported on the influence of exogenous and endogenous cannabinoids on future drug consumption, and Keeley and colleagues illustrate the necessity of implementing sex and strain variables in experimental designs when addressing such research questions. As such, the authors' findings provide a more informative story that will be useful in guiding legislation on marijuana use policies. The introduction of this article provides clear explication of hypotheses and expected results as well as suitable background information that warrants investigation of the authors' research questions. However, there are some minor issues regarding the presentation of methods and statistical results. Additionally, there are some aspects of the discussion that could benefit from citation of supporting literature.

\section{Methods}

In the statistical analysis section, the authors indicate that effect size and statistical power would be reported for all results (pg. 5), yet these data are not provided when presenting results in text. The analytical approaches utilized by the researchers are appropriate for the data; although, brief explanations of post-hoc statistical tests should be included.

It is stated in the Subjects section (pg. 3), that all rats were purchased and shipped from Charles River. However, in the first paragraph of the discussion, the authors allude to an effect of rearing environment on d-amphetamine sensitivity. Specifically, Long Evans females bred in-house showed CPP to the $0.7 \mathrm{mg} / \mathrm{kg}$ dose, but this was absent in Long Evans females obtained from a 
commercial breeder. These data are valuable and should be included, but the analyses do not appear anywhere in the manuscript.

Inclusion of an experimental timeline would increase the clarity of the researchers' methodological approach. It would also provide a useful model for future researchers interested in testing the effects of THC administration on the reinforcing effects of drugs of abuse.

Given that an observer scored dwell time in the CPP chambers, it would be beneficial to include the familiarity of the observer with animals' drug treatment group. In other words, were the observers blinded to treatment conditions?

The authors state that 3 doses of D-amphetamine were used, but only 2 doses are listed ( 0.5 and $0.7 \mathrm{mg} / \mathrm{kg})$. We assume that the third dose is the vehicle $(0 \mathrm{mg} / \mathrm{kg})$, but that should be explicitly listed in the Methods (see pg. 3).

\section{$\underline{\text { Results }}$}

The results are clearly and concisely stated, and the provided figures summarize the data well. However, Table 1 referenced in the "Experiment 1: Determination of a subthreshold dose of damphetamine" section and Table 2 referenced in the "Experiment 2: CPP to a sub-threshold dose of amphetamine" section are not provided in the article (see pg. 5).

In the caption for Figure 1, there is a space inserted into the word "Note". Also in this caption it is stated that mean and "SEE" are provided. Presumably this was supposed to read SEM.

The authors state that estrous cycle did not have any effect on the results (pg. 5). However, with only an $\mathrm{N}=8$, it may simply be that there was not sufficient power to detect any differences. This should be briefly mentioned as a potential caveat.

\section{Discussion}

On pg. 8, the authors indicate that "this study does not support a link between adolescent THC exposure and sensitivity to other drugs of abuse...". Given that only sensitivity to d-amphetamine was assessed, it may be more reasonable to conclude from the provided results that adolescent THC exposure does not enhance sensitivity to d-amphetamine specifically.

On pg. $7-8$, the authors suggest that "...given the increased abuse of prescription opiates, research examining the interplay between the endogenous cannabinoid and opioid systems could potentially prevent the transition of using marijuana to opiates." This is an exciting prospect for future research, and some progress has been made in this regard. The authors may find it useful to include conclusions from Markos et al., (2017) ${ }^{1}$ in which cannabidiol is shown to attenuate morphine CPP in mice.

\section{References}

1. Markos JR, Harris HM, Gul W, ElSohly MA, et al.: Effects of Cannabidiol on Morphine Conditioned Place Preference in Mice.Planta Med. 2018; 84 (4): 221-224 PubMed Abstract | Publisher Full Text

\section{Is the work clearly and accurately presented and does it cite the current literature?}


Is the study design appropriate and is the work technically sound?

Yes

Are sufficient details of methods and analysis provided to allow replication by others? Yes

If applicable, is the statistical analysis and its interpretation appropriate?

Yes

Are all the source data underlying the results available to ensure full reproducibility? Yes

Are the conclusions drawn adequately supported by the results?

Yes

Competing Interests: No competing interests were disclosed.

Reviewer Expertise: Endocannabinoids, cannabis, stress, reward, sex differences

We confirm that we have read this submission and believe that we have an appropriate level of expertise to confirm that it is of an acceptable scientific standard.

Author Response 10 Sep 2018

Robin Keeley, University of Lethbridge, 4401 University Drive, Lethbridge, Canada

We thank the Referees for their thought-provoking as well as useful suggestions. We have addressed all the comments raised through modifications to the manuscript. Specifically, as in response to Dr. Khokar, we have clarified where the subjects were received from. Specifically, rats purchased from Charles River were used to determine the sub-threshold dose of $d$-amphetamine, and the offspring of rats purchased from Charles River and bred at the University of Lethbridge were used for the experiments examining the effects of adolescent THC to the response to amphetamine. To further clarify, we have included a supplementary figure as a timeline.

Competing Interests: No competing interests were disclosed. 
The benefits of publishing with F1000Research:

- Your article is published within days, with no editorial bias

- You can publish traditional articles, null/negative results, case reports, data notes and more

- The peer review process is transparent and collaborative

- Your article is indexed in PubMed after passing peer review

- Dedicated customer support at every stage

For pre-submission enquiries, contact research@f1000.com 